\title{
Methodological Foundations of Creating a Quality Management System of Business Processes on The Principles of Sustainability at The Fashion Industry Enterprise
}

\author{
Svitlana BONDARENKO ${ }^{{ }^{*}}$ \\ ${ }^{1} \mathrm{PhD}$ Candidate (Economics), Associate Professor, Kyiv National University of Technologies and Design, Kyiv, Ukraine; \\ E-mail: sm.bondarenko4610@ukr.net \\ * Corresponding Author
}

\begin{abstract}
Received: 07.11.2021 Accepted: 08.12.2021 Published: 01.02.2022 DOI: 10.47750/QAS/23.186.33
\section{Abstract}

Today, the enterprises competition for consumers is at the level of competition of models and management systems. The quality management system of business processes on the principles of sustainability, which meets the requirements of international standard ISO 9001:2015, is a modern tool that allows fashion industry enterprises form a competitive advantage of a high rank. The conceptual model of such system was proposed and developed methodological approaches to its creation at the fashion industry enterprises. The impact of the functioning of management systems that meet the requirements of international standards ISO on the financial results of the fashion industry enterprises has been studied.
\end{abstract}

Keywords: quality management system of business processes on the principles of sustainability; fashion industry; international standard ISO 9001: 2015; environment; sustainability; requirements; quality; consumer.

\section{Introduction}

In today's world, the processes of globalization encourage enterprises and organizations to constantly look for ways to ensure a high level of quality and competitiveness of products and services. Experience shows that in modern globalized market enterprises compete with each other through the development and implementation of advanced management models and systems. The quality management system of business processes on the principles of sustainability, which meets the requirements of the international standard ISO 9001:2015 is a tool that allows enterprises and organizations to form competitive advantages of a high rank in the market.

Under the conditions of globalization, to ensure a high level of quality, not only appropriate material base and qualified personnel is needed, but also a well-organized organization of work, including precise management of the quality of business processes. The company must create an effective management system that directs the efforts of the company to the quality of all processes, which, in return, will achieve high quality products and services, greater transparency of the enterprise, protection of hired labor and environment.

Today, generating profits cannot be the sole aim of the company's functioning. It is necessary to balance the interests of all stakeholders. Sustainability of the enterprise means that it is balanced to meet the interests and demands of all stakeholders. Commercial success of the company is achieved by combining economic, social and environmental responsibility, while using tools that provide for the observance of moral and ethical values, respect for people, environmental protection.

It is necessary to provide sustainable value to customers in order to gain their loyalty. Today, customer loyalty can be obtained through the production and sale of not just quality products at accessible prices, but ones that provide a sense of admiration and satisfaction. Moreover, modern consumers believe that high-quality and safe products and their production process must be eco-friendly and not harmful to the environment. It is therefore also important to provide sustainable values to the company's own staff, the public and the natural environment.

The issues of ethical business conduct and protection of the environment are topical today. According to the UN Environment Programme study, the fashion industry is responsible for $20 \%$ of global industrial wastewater and $10 \%$ of carbon dioxide emissions, which is more than all international flights and maritime transport combined. Textile manufacturing has been recognized as the second source of water pollution in the world, and a typical pair of jeans requires close to 8,000 litres of water to produce. (Ecomoda: the largest fashion companies agreed to protect the environment (2021).

There are cases when manufacturers of clothes, shoes and expensive accessories have been accused of the fact that the workers who produce their products work in inhuman conditions. The production of fashion products may cause damage to enviroment. The most tragic and technogenic accident at fashion factories is the collapse of the Rana Plaza production building, which occurred in 2013 in Bangladesh. Consumers stopped buying goods of fashion brands and even went to pickets.

Therefore, at the enterprises of fashion industry it is necessary to create management systems that are focused on satisfying the demands of consumers with high quality 
products. However, it must take into account the aspects for the protection of life, health and wellbeing of workers, who produce these products, as well as the protection of the natural environment.

\section{The Purpose}

The purpose of the study is to develop methodological, methodical and practical recommendations for the creation on a fashion industry enterprise quality management system of business processes on the principles of sustainability, which meets the requirements of the international standard ISO 9001:2015.

Proceeding from the set goal in the article the following tasks were set and solved:

- Analyze the definition of "quality management system" concept;

- Define a business process quality management system based on the principles of sustainability that meets the requirements of ISO 9001: 2015;

- To develop a conceptual model quality management system of business processes on the principles of sustainability, which meets the requirements of the international standard ISO 9001: 2015 in the fashion industry;

- Develop a model for creating a business process quality management system in the fashion industry;

- To study the impact of functional management systems that meet the requirements of international ISO standards, on the financial performance of enterprises in the market of fashion products.

\section{Theoretical Background}

In the fast-changing and often unfavorable market environment in which modern enterprises operate, the importance of establishing advanced management systems that meet international standards and provide competitive advantages, competitiveness and implementation of competitive strategies has increased significantly. Despite the wide range of scientific research in this area, these problems require further consideration and improvement.

The issues of research and development of quality management systems in enterprises and organizations are the subject of a significant number of scientific works. Theoretical basis for creating a quality management system is formed in the works of Balog Andrash (2002), Mark Hammar (2021), Mozolyuk V. O. (2005), Momot O. I. (2007), Tricker R. (2020), Vinogradov L. V., Semenov V. P., Burylov V. S. (2016), Topolnik V. G. (2012), Sakhartseva I. I., Lyshchenko E. G. (2004), Yagodzinsky V. A., Kabakov Yu. B. (2009), Vakulenko A. V., Garafonova O. I., Garbuz N. A. (2010), Ogvozdin V. Yu. (2002), The issues of combining quality assurance requirements, environmental requirements and sustainable development are devoted to the works of Levshin V. V. (2001) and Kalyta P. (2020).

However, the creation of modern high-performance quality management systems in enterprises and organizations remains an unsolved methodological and practical problem.

The top management of any enterprise or organization is faced with the task of quality management in order to achieve strategic goals. This can be achieved using a variety of methods and tools: benchmarking, reengineering, six sigma approach, balanced scorecard system, etc. Works Condo Yoshio (2007), Fomichev S. K., Starostina A. A., Skryabina N. I. (2002), Glichev A. V. (2001), Kasych A., Yakovenko Y., Tarasenko I. (2019), Tsalko T., Nevmerzhytska S., Didenko Ye., Kharchenko T., Bondarenko S. (2020), Loiko D. P., Votchenikova O. V., Udovichenko O. P., Kotlyar M. A. (2010), Kasych Alla Horak Jakub; Glukhova Valentyna, Bondarenko Svitlana (2021) are devoted to the study of methods and tools of enterprise management. Each organization independently or with the help of qualified consultants determines which improvement tools are more suitable for it.

With the aim of ensuring high quality of products and services in the quality management systems at enterprises used statistical methods of quality management, which ensure proper collection, quantitative analysis of information and accurate interpretation of the results. Statistical methods of quality management were analyzed in the works of Vardeman Stephen B., Job J. Marcus (2003)

Zakhozhay V. B. , Black A. Yu. (2005).

Today it is not enough for the enterprises to meet the requirements of domestic and international standards and have a certificate of conformity for quality management system. Competitive struggle for the consumer has long been above the standards. The most progressive approaches in world practice oriented at exceeding standard norms are socially-oriented concepts of total quality management TQM and the business excellence model EFQM which were studied by Evans James R. (2007), George S., Weimerskirch A. (2002), Livinsky O. M., Savenko V. I., Palchyka S. P., Chertkova O. Y. (2018).

The issue of corporate social responsibility of the company as a component of overall quality management, encourages the company to take into account the interests of society, to take responsibility for the impact of the company's activities on stakeholders. Aspects of corporate social responsibility are considered in the works Kasych A., Suler P., Rowland Z. (2020), Kasych A., Vochozka M. (2018), Skrypnyk M., Radionova N., Vlasiuk T., Bondarenko S., Grygorevska O. (2019), Kasych A., Kozhemiakina S., Vochozka M. Romanenko O., Glukhova V. (2019).

The aspects presented in the study of quality management, confirm its universality and the need to deepen the theory and methodology, which must ensure the formation of an appropriate basis for increasing the efficiency of management.

\section{Results}

\subsection{Formation of a methodology for developing a quality management system on the business processes based on the principles of sustainability}

The Quality Management System (QMS) is defined as a formalized system that documents the processes, procedures and responsibilities for achieving the policy and quality objectives. QMS helps to coordinate and direct the activities of the organization to meet customer and regulatory requirements and to continuously improve its efficiency and effectiveness.

Let us introduce the main definitions of the concept of quality management system (Table 1) 


\section{GENERAL MANAGEMENT}

\begin{tabular}{|c|c|}
\hline Author, source & Definition \\
\hline ISO 8402:1994 & $\begin{array}{l}\text { Totality of organizational structure, methods, processes and resources required for quality } \\
\text { management }\end{array}$ \\
\hline $\begin{array}{l}\text { ISO 9000:2015. } \\
\text { Fundamentals and glossary }\end{array}$ & $\begin{array}{l}\text { Part of the management system in terms of quality. The management system is a totality of } \\
\text { interconnected or interoperable elements of the organization to formulate policy, set goals and } \\
\text { processes to achieve the goals. }\end{array}$ \\
\hline Mark Hammar (2021) & $\begin{array}{l}\text { Quality Management System, often called a QMS, is a set of internal rules that are defined by a } \\
\text { collection of policies, processes, documented procedures, and records. This system defines } \\
\text { how a company will achieve the creation and delivery of the products and services they provide } \\
\text { to their customers. }\end{array}$ \\
\hline $\begin{array}{l}\text { Vakulenko A. V., Garafonova } \\
\text { O. I., Garbuz N. A. (2010) }\end{array}$ & $\begin{array}{l}\text { The quality management system is a part of the organization's management system aimed at } \\
\text { achieving results in accordance with the goals in the field of quality and at satisfying the needs, } \\
\text { expectations or demands of the interested parties. }\end{array}$ \\
\hline Tricker R. (2020) & $\begin{array}{l}\text { A Quality Management System is neither a manual (i.e. a document) nor a computer program } \\
\text { (which is an information system as opposed to being a real quality system). It is a system that } \\
\text { contains all the things used to regulate, control and improve the quality of your products and/or } \\
\text { services. It is a network of interrelated processes with each process being made up of people, } \\
\text { work, activities, tasks, records, documents, forms, resources, rules, regulations, reports, } \\
\text { materials, supplies, tools, equipment etc. that are required to transform inputs into outputs. }\end{array}$ \\
\hline $\begin{array}{l}\text { Loiko D. P., Votchenikova O. } \\
\text { V., Udovichenko O. P., } \\
\text { Kotlyar M. A. (2010) }\end{array}$ & $\begin{array}{l}\text { Quality management system is a system of documentation that establishes the general } \\
\text { principles of quality assurance, requirements for the activities and responsibilities of each } \\
\text { employee in the field of quality; conditions for compliance with the specified parliaments of each } \\
\text { process and characteristics of each object; methods of control, processing and analysis of } \\
\text { quality information; training programs for personnel in the field of quality, etc. }\end{array}$ \\
\hline Ogvozdin V.Yu. (2002) & A set of structures that perform functions of quality management using defined methods. \\
\hline Glichev A.V. (2001) & $\begin{array}{l}\text { Product quality management system is a method for organizing efficient interaction between the } \\
\text { management and administrative units and individual employees who participate in the creation } \\
\text { and production of goods, its implementation, use and maintenance with the aim of providing } \\
\text { properties, which ensure the satisfaction of certain requests of customers at the minimum } \\
\text { expenditure of effort and resources. }\end{array}$ \\
\hline Topolnik V. G. (2012) & $\begin{array}{l}\text { A set of structures that perform functions of management and quality assurance using the } \\
\text { defined methods. }\end{array}$ \\
\hline
\end{tabular}

Table 1: Definition of the quality management system

The international standard ISO 8402 (1994) defines a quality management system as a set of organizational structure, processes and resources, methods and tools for their achievement. The latest version of the ISO 9000: 2015 standards defines the quality management system as part of a management system with regard to quality.

As can be seen from Table 1, most of the authors have the opinion that quality management system is part of the general management of the organization; it sets goals in the field of quality and ensures the achievement of these goals.

Glichev A. V. (2001) believes that quality is a way of organizing efficient interaction between management and administrative units and individual employees who take part in the creation and production of goods, its implementation, use and maintenance with the aim of providing its properties, which ensure the satisfaction of certain requests of customers at the minimum expenditure of effort and resources.

The most comprehensive definition of the quality management system is given by Ray Tricker (2020). The author considers the quality management system as a system comprising all the tasks used to regulate, control and improve the quality of products and services.

The rapid changes that are taking place in the market of fashion products make it necessary to search for new approaches, principles, methods and tools for the company's operations. One of these tools is the creation of quality management system on the principles of sustainability, which meets the requirements of the international standard ISO 9001:2015.

Modern management systems must ensure the high quality of all processes that take place at the enterprise and which are focused primarily on satisfying the needs of the customer. The requirement of today - transparency of activity and comprehensive protection of life and health of workers and the natural environment. It is proposed to use the term "quality management system of business process on the principles of sustainability, which meets the requirements of the international standard ISO 9001:2015". The quality of business processes of the company crucially affects the quality of the company's product and the quality of the enterprise management system. Let us introduce our own definition of quality management system of business processes on the principles of sustainability, which complies with the requirements of ISO 9001:2015.

The quality management system of business processes on the principles of sustainability, which meets the requirements of the international standard ISO 9001:2015 is a system of overall management of the enterprise, which provides a balanced satisfaction of the needs of all stakeholders by providing a sustainable value for customers, shareholders, staff, environment and the entire society in general.

Benefits for fashion industry enterprises from the implementation of an effective quality management system of business processes are:

Improving the quality and competitiveness of fashion products;

More customer satisfaction, ensuring their loyalty; Increasing the efficiency of business processes;

Increasing the efficiency of use of all types of resources;

Reduction of defects and losses from defects, reduction of production costs;

Formation of loyalty and commitment of employees;

Protection of the natural environment;

Ensuring the transparency of enterprise's activity;

Formation of ethical behavior of the manufacturer on 


\section{GENERAL MANAGEMENT}

the market, his corporate social responsibility, ability to act as an aware corporate citizen;

Improvement of coordination and interaction between structural divisions and departments of the company.
The conceptual model quality management system of business processes on the principles of sustainability of fashion industry enterprise was developed (Fig. 1).

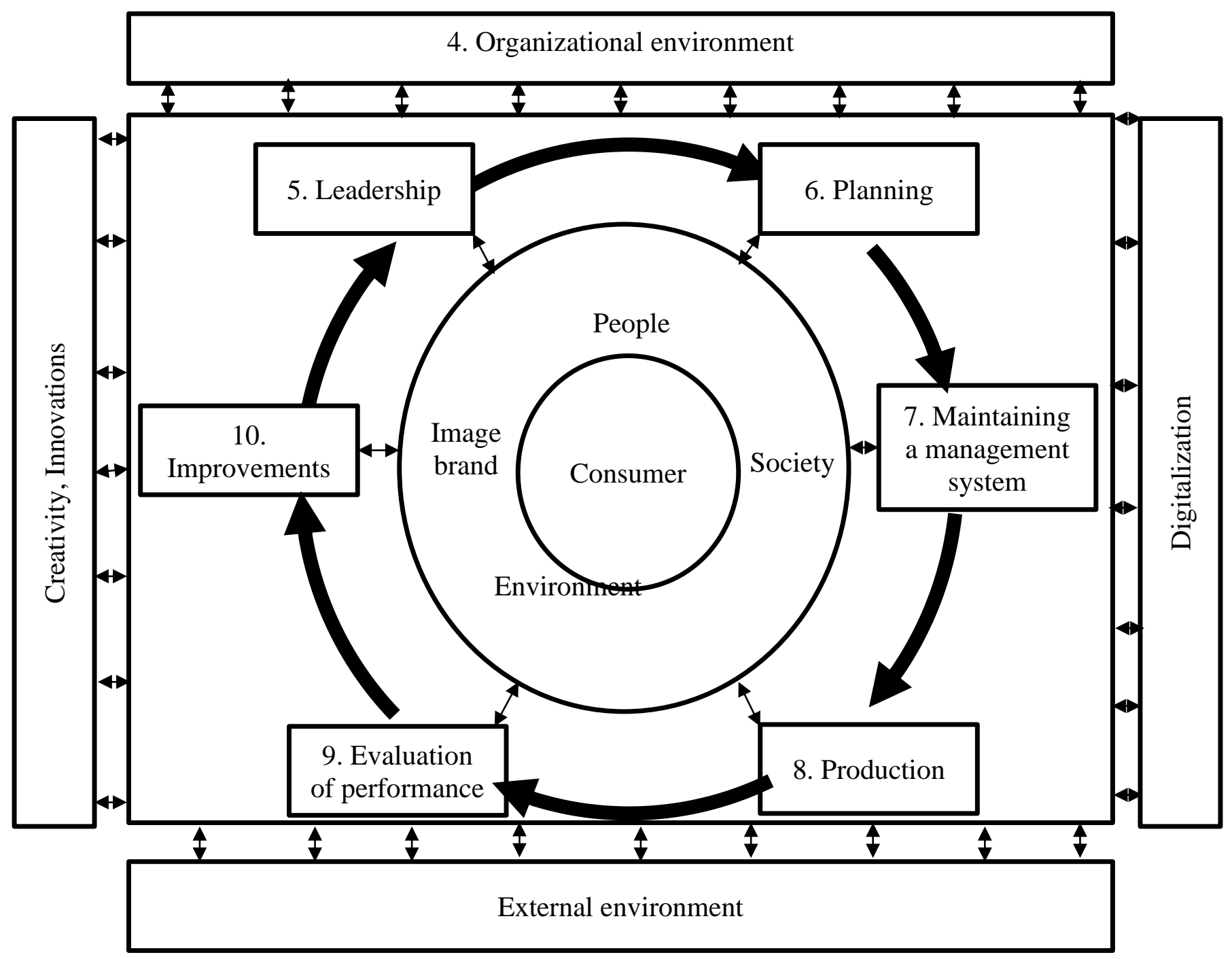

Fig. 1: Conceptual model quality management system of business processes on the principles of sustainability in the fashion industry enterprise, which meets the requirements of ISO 9001:2015 Developed by the author

In the center of the model is consumer. At the current stage of development of technology, in order to outperform in the competition, it is necessary to meet the demands of consumers of apparel and shoes, not just fully, but at such a level as to excite their admiration.

The special feature of satisfying the demands of fashion industry consumers is the necessity to take into account fashion trends. If earlier fashion could be presented in the form of a pyramid, where high fashion is located on top of the pyramid, a pret-a-porter (ready-to-wear) is behind it, and mass-market is situated at the core of the pyramid, today this approach no longer exists. Designers of footwear and apparel companies are orient for an intelligent buyer who can combine products of different fashion levels in one image, creating collaborations.

Ensuring the high quality of clothing and shoes will allow consumers to use them for a long time, and not send them to the disposal site at the earliest possible moment, polluting the environment. The modern consumer believes that the products themselves, as well as the process of their production must be environmentally friendly and not harmful to the environment. Today's high quality, fashionable clothes and shoes, which are manufactured by famous brands have become available to all people, not only for the top class. Much of the credit for this belongs to the enterprises of fashion industry. But there is also a price for the fact that this opportunity is used by a large number of consumers. And this price is the overexploitation of workers in countries with cheap labor and pollution.

Important for enterprises of fashion industry as any other industry is the image of the brand. Modern consumers desire to wear clothing and shoes branded known manufacturers. Brand image - a complex of emotions, which the product evokes in the consumer. According to research, brand image is sometimes even more important for modern consumers, especially for young people.

The peculiarity of the fashion industry enterprises is the important role of creativity, as the design of clothes, shoes, 


\section{GENERAL MANAGEMENT}

accessories in a crucial way depends on the creativity and innovations of both designers and model-makers. The main creatives in the fashion industry enterprise are undoubtedly the fashion designers, whose task according to White $\mathrm{N}$. and Griffiths I. (2018) is "to divine unconscious collective desires". But not only designers need to be creative. Creativity concerns all the staff of the fashion industry enterprises. This is how the industry works. Consumers want to see fashionable, modern, environmentally friendly fashion products, so creativity is needed in the production of materials and components from which fashion products are made, and in the use of advanced technology and techniques, and in the sale of products, i.e. at all stages of the life cycle of fashion products.

The fashion industry enterprise is a creative organization that actively interacts with the external environment and sees it not as a source of danger and threats, but rather as a basis for the generation of creative ideas. Activation of this interaction stimulates more and more creativity and creates conditions for generation of ideas in enterprises of fashion industry. It is proposed in the quality management systems of business processes on the principles of sustainability in the enterprises of fashion industry to include not only the audit of compliance with the requirements of ISO 9001:2015, as well as monitoring of indicators of innovativeness, such as the number of creative ideas, innovations, sources of their emergence and commercialization.

The quality management system of business processes on the principles of sustainability must provide the conditions for creative ideas generation and use tools and methods of psychological activation of thinking.

Fashion industry enterprises as creative organizations are those that are self-trained. Professional development of the staff is its training, gaining and development of certain competencies. The organization, which is trained itself creates, develops, transfers and stores knowledge. It is able to successfully change its behavior in accordance with the new knowledge.

Globalization has given new relevance to the efforts to support digitalization of fashion industry enterprises, which have a great potential for the development of business models and the creation of new products and services, increasing productivity and, in the end, increasing business efficiency, so the model quality management system of business processes on the principles of sustainability requires the active use of digitalization.

The part of the model in Fig. 1 that enforces the requirements of international standard ISO $9001: 2015$ is the outer circle of the section names of the international standard. We would like to remind, that the international standard ISO 9001:2015 today is the most leading and most acknowledged approach to the development of quality management systems. This standard relates not only to quality management systems, but specifies the requirements for the entire enterprise management system.

\subsection{Development of methodical approaches to the creation quality management system of business processes on the principles of sustainability in the fashion enterprises}

Development and implementation of quality management system of business processes on the principles of sustainability in enterprise is, in essence, the implementation of the model project.

The performance of any project is characterized by the following parameters:

- known start and end dates;

- necessary resources (money, office equipment, premises, personnel);

- the sequence of stages, each of which is characterized by certain works and persons responsible for their implementation;

- criteria for the success of the stages.

Development and implementation process quality management system of business processes (QMSBP) as a project can be divided into the following project stages (Fig. 2). 


\section{GENERAL MANAGEMENT}

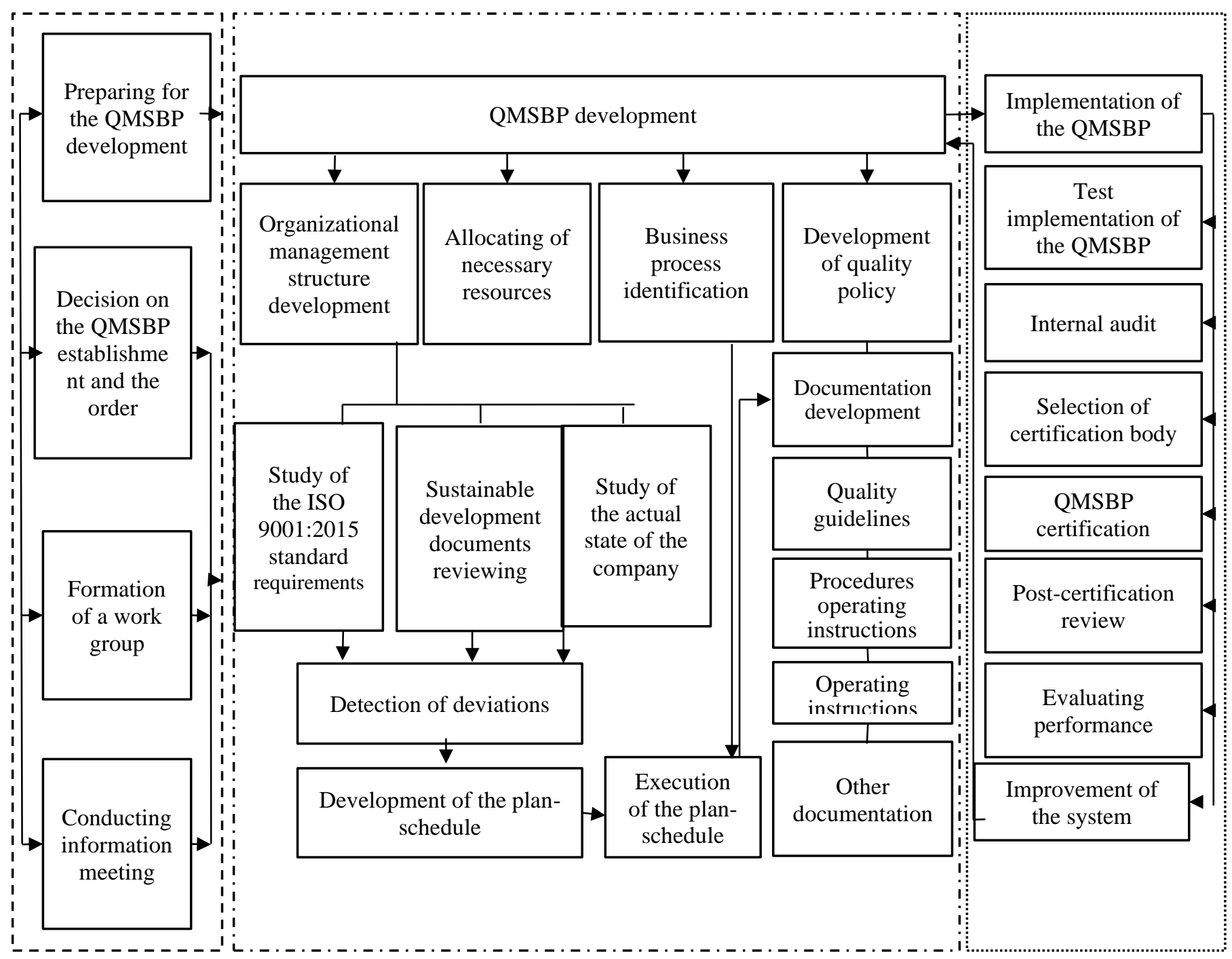

Fig. 2: Model quality management system of business processes on the principles of sustainability in the enterprise of fashion industry Developed by the author

Development quality management system of business processes on the principles of sustainability, which meets the requirements of the international standard ISO 9001:2015, is difficult, labor-intensive and time-consuming work, which is impossible without the establishment of an appropriate organizational structure of the enterprise. System development management admits conducting a significant amount of work, which requires simultaneous participation of various departments of the enterprise. To organize and coordinate such work, as well as for capturing collegial decisions on the most important issues of development, implementation and functioning of the business processes quality management system, is advisable to create a Coordination Council, which is headed by the first head of the enterprise. The owners of all processes are included in its composition. Practically, they can be heads of departments. This structure allows the Council to make decisions on any matter of activity of the company. Except for control, organization and coordination of the development of quality management system of business processes, the meetings of the Council may consider any matter. The Council may discuss any issues related to improving the quality, environmental quality of products, sustainable development, competitiveness of the company, improvement of its activities, etc.

Development quality management system of business processes requires a significant amount of specific work on the planning and implementation of the necessary steps of the project. To perform these works should be allocated appropriate staff. At large enterprises, which have more than 250 employees, it can be a group (department) of quality management. At smaller enterprises - engineer (technician, manager) in quality management.

To ensure and maintain in working order of the quality management system of business processes at the enterprise distinguishing of the necessary resources is required: human, material, financial.

International standard ISO 9001:2015 "Quality management systems. Requirements" specifies requirements for the organization to define processes required for the quality management system (clause 4.4.). For effective functioning of an enterprise it is necessary to define a number of interrelated and interoperable business processes and to manage them. Often, the output from one process is the input of the next one. Systematic identification of processes, especially their interaction and management is called a "process approach". Management of any process, in general, is carried out in the form of a continuous closed cycle by E. Deming "P (Plan) - D 
(Do) - C (Check) - A (Act)".

The enterprise process can be managed only when a level of responsibility is defined for it. A process owner or manager ("process manager" or "case manager") is designated, to whom resources and responsibilities are assigned. He or she is responsible for the efficiency and effectiveness of the process.

Implementation of the QMSBP at fashion industry enterprise demands studying the requirements of ISO $9001: 2015$, recommendations of the 17 principles of sustainable development for the period 2015-2030, 10 UN Global Compact Goals, Fashion Pact G7 and the Fashion Industry Charter for Climate Action.

Then the actual state of the current enterprise management system is determined and the extent to which the requirements and recommendations identified at the previous stage are fulfilled is assessed. Practically it can be an external audit with participation of the quality management department members, external consultant. During the audit may be conducted visits to various departments of the company, interviews with employees, study of actual activities, current documents. This can be done using prepared questionnaires.

If in the process of analysis the non-compliance of the enterprise with the requirements of the international standard is revealed, the non-compliance is fixed and for each such fact an event should be taken to bring the enterprise into compliance with the requirements.

Developing a quality management system of business processes, requires a large amount of work in various departments of the organization, so it is convenient to bring all these activities in a single integrated plan, the activities that can be divided into two parts:

- Development of the business process quality management system documentation;

- Plan of stages to bring the practical activities of the company into compliance with the requirements of the international standard ISO 9001:2015 and the principles of sustainable development.

The second part of the complex plan should include measures to eliminate inadequacies in the company's activities in accordance with the requirements of the international standard ISO 9001:2015 and internal contraventions, which were mentioned above. It is also mandatory to include measures for training of all personnel in the field of quality and informing the team about the progress of development and implementation of the business processes quality management system.

The complex plan should include responsibility for the implementation of activities and dates of their implementation. For works on both parts of the complex plan it is advisable to plan parallel execution in order to reduce the total term of development of the quality management system of business processes.

One of the main documents, in accordance with which is planned and carried out all activities within the business processes quality management system is the policy of the enterprise quality. Policy in the enterprise of quality - general intentions and directions of organization related to the quality, it is officially formulated by the top management. The current situation is the inclusion to the Policy the goals of the enterprise in the field of sustainable development. Properly developed policy is the key to the competitiveness of the enterprise in the market and efficient functioning of its business processes quality management system.

To determine the quality objectives, however, it is necessary to identify measurable parameters that characterize the position of the policy of the company in the field of quality.
Among them there can be indicators used for questioning customers and staff (e.g., the level of satisfaction with the quality, prices, delivery conditions, packaging, transparency of the company and so on). To determine the goals, indicators that reflect the interests of the company itself (e.g., total production, revenue, market share), the interests of the staff (e.g., the level of motivation, working conditions, level of training) and the interests of other interested parties can be used.

At the end of the planning period, the top management analyzes the functioning of the quality management system of business processes, and on the basis of this analysis is developed policy, objectives, the company's plans for the next period, that is carried out the next step along the lines of continuous improvement of the enterprise.

Advanced implementation quality management system of business processes can begin after the completion of documentation development and bringing the activities of the company in compliance with the requirements of ISO 9001:2015 and this documentation. All developed documentation is reproduced in the required quantity and distributed among employees in accordance with the methodology of documentation management. From this moment the company begins to operate in accordance with the requirements of ISO $9001: 2015$ and documentation.

Even with the best preparation for the implementation quality management system of business processes, there is a risk that some nuances of the company's activities will be missed and not reflected in the documents. This can lead to what is "physical" execution of requirements of the system quality documents of business processes will be impossible, complicated or in general lead to negative results. To prevent this possibility, it is advisable to introduce a test period of QMSBP implementation during which it is allowed to deviate from the requirements of the documentation. But at the same time the relevant substantiated information must be temporarily transferred to the quality management department, which promptly consider this information and, if necessary, prepare designs for changes in the documents of the quality management system of business processes.

Having implemented quality management system of business processes, the management of the organization should check how it functions, where faults in the system occur, and evaluate its effectiveness. Results of internal audits provide this kind of information. Quality audit is a systematic, independent and documented process of obtaining objective evidence of the audit and its general goal is to determine the level of compliance with the audit criteria (ISO 9000 :2015). Internal audit is carried out by personnel who are not directly responsible for those areas of activity that are subject to a quality audit. The goal of the audit is to assess the effectiveness of the conducted measures to determine the need for corrective actions, as well as measures for improvement.

Certification is the final stage of creating a quality management system of business processes and is carried out to ensure stakeholder confidence in the fact that the products manufactured by the company, meet the mandatory requirements of regulatory documents, all technical, administrative and human factors that affect the quality of products are under control, the products which unsatisfy quality requirements is revealed, and the company is implementing measures to prohibit the manufacture of such products on a continuing basis. Before certification company must apply certification body. It can be recommended that certification bodies include in the list of indicators for which the management system review is carried out indicators that characterize the protection of environment and oversight of the 


\section{GENERAL MANAGEMENT}

operation of the company. The results of certification are executed by the certificate, which is sent to the applicant. Certificate of QMSBP for the consumer, which is purchased products of the company, means a guarantee of quality of procurement, the transparency of the activities of the company and its corporate social responsibility, affiliation with the principles of sustainable development.

\subsection{Study of the impact of functioning management systems that comply with ISO on financial performance of fashion industry enterprises}

Functioning quality management system for the business processes on the principles of sustainability, which meets the requirements of ISO $9001: 2015$, leads to improved product quality, increased loyalty of customers and staff of the company, ensures the protection of environment.

Study of the impact of functioning management systems that meet the requirements of ISO standards on the performance of enterprises can be carried out on the application of the world leaders, producers of well-known sportswear and sport shoes brands, including Nike, Adidas, Puma, Reebok, ESPN, Gatorade, Sky Sports, Under Armour, UFC, YES and others. All of them have management systems that meet the requirements of international ISO standards, such as:

- ISO 9001:2015 "Quality Management Systems.

\section{Requirements";}

- ISO 14001:2015 "Environmental management systems. Requirements with guidance for use";

- ISO 45001:2018 " Occupational health and safety management systems. Requirements with guidance for use";

- ISO 50001:2018 "Energy Management Systems. Requirements with guidance for use" and others.

The most expensive sports business brands in the world in 2019 (in millions of USD) are shown in Fig. 3. As you can see leading world sports brands and have a high market value. Nike has the highest market value.

Let us look at how the presence of the quality management system affects the financial performance of the fashion industry. Functioning of the quality management system leads to increase in the quality of products, which, in return, ensures a positive reputation for the manufacturer of these products. Reputation is an important factor in business. The indicators of business reputation are the level of trust in the enterprise, which is determined by social and psychological polls, and goodwill - the market value of business reputation. Goodwill is a non-material asset whose value is defined as the difference between market price and book value of the company's assets. Reputation and goodwill is crucially formed on the basis of achieved for the previous and the current period of time the level of quality of products that are produced, the level of customer service, marketing, commercial support products and others.

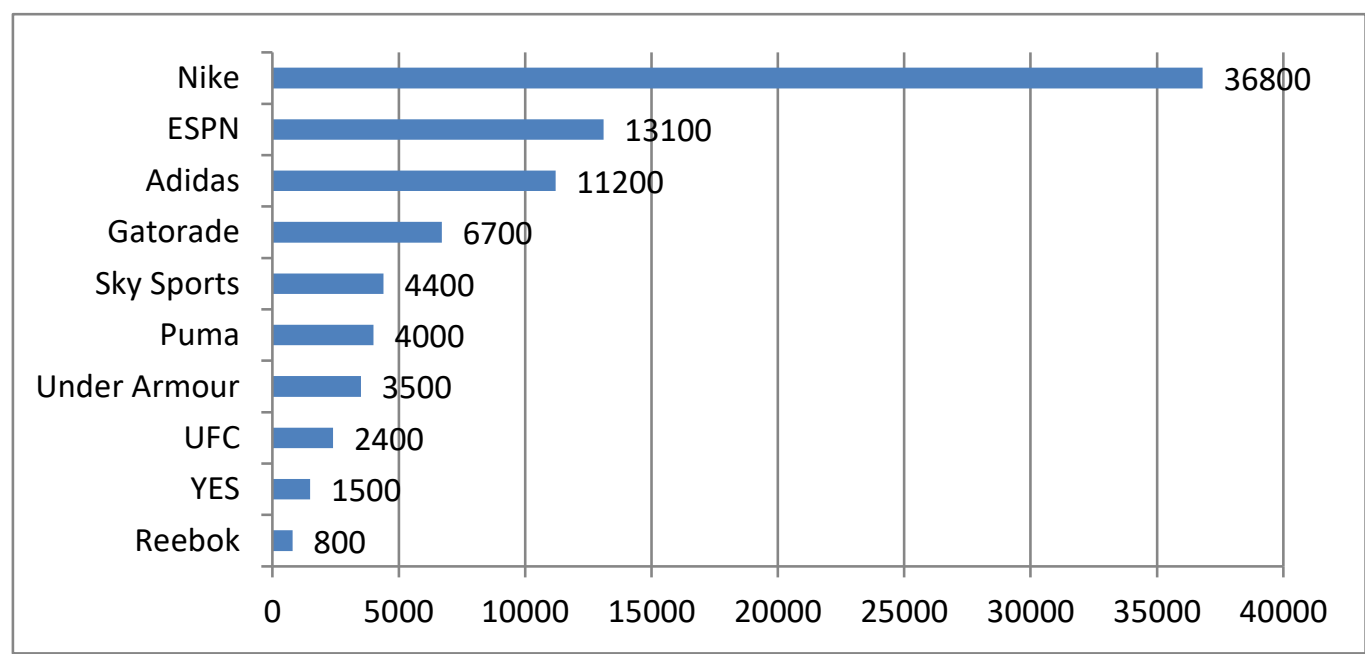

Fig. 3: Market value of leading sports business brands worldwide in 2019 (in millions of USD) Source: Statista.com

Therefore, the company's goodwill, which is reflected in the financial statements of enterprises, can be regarded as an indicator of the achieved level of quality of products and services.

In addition, an indicator of the achieved level of quality in the production of clothing and shoes can be royalty - a type of license fees, monetary compensation for the use of corporate brands or logos, which have already gained prominence and popularity. Sales of licenses for use brand name, fashion brand is very widespread for fashion industry enterprises. Royalty is reflected in the statement of financial results of the enterprise.

Improving the quality of products and services ensures high competitiveness of the company, creates a positive reputation for the manufacturer on the market. Quality products increase the market share, which, in turn, helps to survive in the market, increase the volume of sales, reduce costs, increase income and profit.

Result of the creation of quality management systems is improved interaction and coordination of work between departments and divisions of the enterprise, as well as individual performers. This also leads to the optimization of management decisions, which allows reduce the cost of management and, accordingly, to obtain more profits and ensure high profitability.

There is no functional dependence between the financial performance indicators of a company - the amount of income and profit and the quality level. Moreover, there is a certain time lag between the increase in quality and profit growth. But there is still a correlation link, and we will try to identify it based on the data given in Table 2, where the performance indicators of the leading international companies - manufacturers of sportswear Adidas and Puma are presented. 
GENERAL MANAGEMENT

\begin{tabular}{|c|c|c|c|c|c|c|c|c|c|c|}
\hline Indicators & 2011 & 2012 & 2013 & 2014 & 2015 & 2016 & 2017 & 2018 & 2019 & 2020 \\
\hline \multicolumn{11}{|c|}{ Adidas Group, million euros } \\
\hline Net sales & 13,322 & 14,883 & 14,203 & 14,534 & 16,915 & 18,483 & 21,218 & 21,915 & 23,640 & 19,844 \\
\hline Gross profit & 6,239 & 7,103 & 7,001 & 6,924 & 8,168 & 9,100 & 10,703 & 11,363 & 12,293 & 9,855 \\
\hline $\begin{array}{l}\text { Royalty } \\
\text { commission income }\end{array}$ & 93 & 105 & 103 & 102 & 119 & 105 & 115 & 129 & 154 & 83 \\
\hline Total assets &, 237 & 11,651 & 11,599 & 12,417 & 13,343 & 15,176 & 14,019 & 15,612 & 20,680 & 21,053 \\
\hline Shareholders' equity & 5,137 & 5,304 & 5,489 & 5,624 & 5,666 & 6,472 & 6,032 & 6,377 & 6,796 & 6,454 \\
\hline Goodwill & 553 & 1,281 & 1,204 & 1,169 & 1,392 & 1,412 & 1,220 & 1,245 & 1,257 & 1,208 \\
\hline $\begin{array}{l}\text { Number of employees, } \\
\text { persons. }\end{array}$ & 46,824 & 46,306 & 49,808 & 53,731 & 55,555 & 58,902 & 56,888 & 57,016 & 65,194 & 62,285 \\
\hline $\begin{array}{ll}\text { Spending } & \text { on } \\
\text { employees } & \end{array}$ & 1,646 & 1,872 & 1,833 & 1,842 & 2,184 & 2,373 & 2,549 & 2,481 & 2,720 & 2,483 \\
\hline \multicolumn{11}{|c|}{ Puma Group, million euros } \\
\hline Indicate & 2011 & 2012 & 2013 & 2014 & 2015 & 2016 & 2017 & 2018 & 2019 & 2020 \\
\hline Sales & $3,009.0$ & $3,270.7$ & $2,985.3$ & $2,972.0$ & $3,387.4$ & $3,626.7$ & $4,135.9$ & $4,648.3$ & $5,502.2$ & $5,234.4$ \\
\hline Gross profit & $1,493.4$ & $1,579.0$ & $1,387.5$ & $1,385.4$ & $1,540.2$ & $1,656.4$ & $1,954.3$ & $1,249.4$ & $2,686.4$ & $2,458.0$ \\
\hline $\begin{array}{l}\text { Royalty and } \\
\text { commission income }\end{array}$ & 17.6 & 19.2 & 20.8 & 19.4 & 16.5 & 15.7 & 15.8 & 16.3 & 25.1 & 16.1 \\
\hline & & & 2 & & 2,62 & & & $3,207.2$ & $4,378.2$ & $4,684.1$ \\
\hline Share & $1,605.2$ & $1,597.4$ & $1,497.3$ & $1,618.3$ & $1,619.3$ & $1,722.2$ & $1,656.7$ & $1,722.2$ & $1,902.3$ & $1,763.9$ \\
\hline Goodwill & & 289,4 & 243,0 & 241,7 & 240,3 & 250,4 & 241,9 & 245,7 & 249,7 & 294,6 \\
\hline $\begin{array}{l}\text { Number of employees, } \\
\text { persons. }\end{array}$ & 10,836 & 11,290 & 10,982 & 11,267 & 11,351 & 11,495 & 11,787 & 12,894 & 14,332 & 14,374 \\
\hline
\end{tabular}

Table 2: Performance indicators of the world's leading sportswear brands

Source: compiled by the author according the enterprises' information Adidas Group and Puma Group

Using correlation and regression analysis by least squares method the impact of goodwill and royalties, which reflect the achieved level of quality, on the results of activity of fashion industry enterprises, namely on the gross profit was determined. So, for the performance indicator $Y$ taken gross profit of enterprises. The factor $X$ is goodwill and royalties. We have a multiplicity correlation. Calculations carried out in Excel allowed to obtain the following results (Table 3).

\begin{tabular}{|c|c|c|}
\hline Company & Model & Multiple correlation coefficient R \\
\hline Adidas group & $\mathrm{Y}=6819.687+67.785 \times 1-4215.570 \mathrm{X} 2$ & $\mathrm{R}=0.715$ \\
\hline Puma group & $\mathrm{Y}=-660.658+62.476 \mathrm{X} 1+4.851 \mathrm{X} 2$ & $\mathrm{R}=0.434$ \\
\hline
\end{tabular}

Table 3: Results of correlation-regression analysis

The relationship model can be used for the purposes of forecasting the companies' revenues based on the achieved level of goodwill and royalties. The obtained values of coefficient of multiplicity correlation in both cases allow us to make a conclusion about the average $(R=0.434)$ and high $(R$ $=0.715$ ) level of interaction.

So we can say that there is a relation between the gross profit of fashion industry enterprises and goodwill and royalties. Therefore, there is a relation between the quality of products, and thus the effectiveness of functioning of the management system, which meets the requirements of ISO, and the financial results of the activities of the company.

\section{Conclusion}

The conducted research enabled to develop methodological and methodical bases for creation quality management system for the business processes on the principles of sustainability, which meets the requirements of the international standard ISO 9001:2015 at the fashion industry enterprises.

Ensuring profits to the owners of the company today cannot be the only goal of the enterprise functioning. In modern systems of management, it is necessary to set a few goals and ensure the means, methods and tools to achieve these goals. It is necessary to balance the interests of all stakeholders. To ensure customer acceptance and loyalty, it is important to provide them with quality products that will make them feel satisfied and admired. As shown by research, modern consumers believe that the most high-quality and safe products, the process of their production and implementation must be eco-friendly. For this conceptual model of quality management system of business processes on the principles of sustainability at a fashion industry enterprise, which meets the requirements of the international standard ISO 9001:2015 is proposed. The system is a tool for providing sustainable values to customers, shareholders, employees, society and the natural environment.

Development and implementation of the business process quality management system on the principles of sustainability, which meets the requirements of ISO 9001:2015, is the implementation of a model project, which is divided into design steps. It is important to use a process approach in the business processes quality management systems on the principles of sustainability.

The influence of management systems functioning on the enterprises, which meet the requirements of international ISO standards on the results of enterprises in the market of fashion products on the application of the leading manufacturers of 
sportswear and shoes, is studied. It was found that there is a medium and tight connection between the functioning of the quality management system, which meets the requirements of ISO and financial performance of the fashion industry enterprises.

\section{References}

[1] Balog Andrash (2002). Quality mosaic. ADEF-Ukraine. Kyiv. $64 \mathrm{p}$.

[2] Condo Yoshio (2007) Company-wide quality management. Publishing house "ADEF-Ukraine". Kyiv. 256 p.

[3] Ecomoda: the largest fashion companies agreed to protect the environment (2021) Available at: https://hochu.ua/catfashion/news/article-96571-ekomoda-krupneyshie-fashionkompanii-podpisali-soglashenie-o-zaschite-okruzhayuscheysredyi/ (Accessed 20 November 2021)

[4] Evans James R. (2007) Total Quality Management. UnityDana. $671 \mathrm{p}$.

[5] Zakhozhay V.B., Black A.Yu. (2005) Quality statistics. MAUP. Kyiv. 576 p.

[6] Fomichev S.K., Starostina A.A., Skryabina N.I. (2002) Fundamentals of quality management. MAUP. Kyiv. 191 p.

[7] George S., Weimerskirch A. (2002) Total Quality Management: Strategies and Technologies Used in Today's Most Successful Companies (TQM). Victoria Plus. Saint Petersburg. 256 p.

[8] Glichev A.V. (2001) Fundamentals of product quality management. RIA "Standards and Quality". Moscow. 424 p.

[9] ISO 9000:2015 Quality management systems Fundamentals and vocabulary. Available at: https://www.iso.org/obp/ui/\#iso:std:iso:9000:ed-4:v1:en. (Accessed 20 November 2021).

[10] ISO 9001: 2015. Quality management systems Requirements. Available https://www.iso.org/obp/ui/\#iso:std:iso:9001:ed-5:v1:en. (Accessed 20 November 2021).

[11] ISO 8402:1994 Available at: https://files.stroyinf.ru/Data1/5/5812/index.htm (Accessed 20 November 2021).

[12] Kalyta P. (2020) System management for sustainable development: models and problems. Management. Issue 2 (32). 93-110.

[13] Kasych A., Kozhemiakina S., Vochozka M., Romanenko O., Glukhova V. (2019). A World Model of Social Entrepreneurship in a Crisis. Journal of Entrepreneurship Education. Vol $22 . \quad$ Available at: https://www.abacademies.org/articles/a-world-model-ofsocial-entrepreneurship-in-a-crisis-8049.html (Accessed 20 November 2021)

[14] Kasych A., Suler P., Rowland Z. (2020) Corporate Environmental Responsibility Through the Prism of Strategic Management. Sustainability. Vol. 12 (22). Available at: https://www.mdpi.com/2071-1050/12/22/9589. (Accessed 20 November 2021)

[15] Kasych A., Vochozka M. (2018) Medothological support of the enterprise sustainable development management. Marketing and Management of Innovations. no. 1. pp. 371-381.

[16] Kasych A., Yakovenko Y., Tarasenko I. (2019). Optimization of business processes with the use of industrial digitalization. Proceedings of the International Conference on Modern Electrical and Energy Systems, MEES. pp. 522-525 Available at: https://ieeexplore.ieee.org/document/8896531 (Accessed 20 November 2021)

[17] Kasych Alla, Horak Jakub, Glukhova Valentyna, Bondarenko Svitlana (2021) The Impact of Intellectual Capital on Innovation Activity of Companies. Quality - Access to
The quality management system of business processes on the principles of sustainability, which meets the requirements of ISO 9001: 2015, is a tool that helps the company to provide sustainable values, to ensure the high quality of business processes and be responsible corporate citizen.

Success. Vol. 22 Issue 182, p 3-11.

[18] Levshin V.V. (2001) Quality Assurance Fundamentals. Krasnoyarsk. $127 \mathrm{p}$.

[19] Livinsky OM, Savenko VI, Palchyka SP, Chertkova OY (2018) Quality management in construction and the genome of business excellence of organizations Center for Educational Literature. Kyiv. $232 \mathrm{p}$.

[20] Loiko D.P., Votchenikova O.V., Udovichenko O.P., Kotlyar M.A. (2010) Quality management. "Magnolia 2006". Lviv. 336 p.

[21] Mark Hammar (2021) Quality Management System: What is it? Available at https://advisera.com/9001academy/knowledgebase/qualitymanagement-system-what-is-it/ (Accessed 20 November 2021)

[22] Mozolyuk V.O. (2005) System quality management. NUS Mykolaiv.104 p.

[23] Momot O.I. (2007) Quality management and elements of the quality system. Center for Educational Literature, Kyiv. 368 p.

[24] Ogvozdin V.Yu. (2002) Quality Management: Fundamentals of Theory and Practice. Business and service. Moscow. 160 p.

[25] Sakhartseva I.I., Lyshchenko E.G. (2004) Formation of a product quality management mechanism at foundry enterprises. Publishing House of the Zaporozhye Engineering Academy. Zaporozhye. 276 p.

[26] Skrypnyk M., Radionova N., Vlasiuk T., Bondarenko S., Grygorevska O. (2019) Accounting and Verification of Sustainable Enterprise Development Reporting. IBIMA Business Review. 2019. Vol. 2019. Available at: https://ibimapublishing.com/articles/IBIMABR/2019/873407/ (Accessed 20 November 2021)

[27] Topolnik VG (2012) Quality management of products and services in the hotel and restaurant industry. Magnolia 2006. Lviv. $328 \mathrm{p}$.

[28] Tricker R. (2020) Quality management systems. A Practical Guide to Standards implementation. Routledge. Taylor and Francis Group. London and New York. 259 p.

[29] Tsalko T., Nevmerzhytska S., Didenko Ye., Kharchenko T., Bondarenko S. (2020) Optimization of goods implementation on the basis of development of business process reengineering. Journal of Management Information and Decision Sciences. 2020. Volume 23, Issue: 2. p. 42-48. Available

at: https://www.abacademies.org/articles/OPTIMIZATION\%20OF \%20GOODS\%20IMPLEMENTATION\%20ON\%20THE\%20BA SIS\%20OF\%20DEVELOPMENT\%20OF\%20BUSINESS\%20 PROCESS\%2ORE-ENGINEERING-1532-5806-23-2-179.pdf (Accessed 20 November 2021)

[30] White N. and Griffiths I. (2018) The fashion business: theory, practice, image. Grevtsov Publisher. Minsk. 272 p.

[31] Vakulenko AV, Garafonova OI, Garbuz NA (2010) Quality management. KNEU. Kyiv. 551 p.

[32] Vardeman Stephen B., Job J. Marcus. (2003) Statistical methods of quality assurance. KNTEU Publishing Center. Kyiv. $251 \mathrm{p}$

[33] Vinogradov L.V., Semenov V.P., Burylov V.S. (2016) Means and methods of quality management. Infra-M. Moscow. $220 \mathrm{p}$.

[34] Yagodzinsky V. A., Kabakov Yu. B. (2009) Quality management systems and internal audit. Ukrainian Association for Quality. Personnel training center "GrowthAcademy". Kyiv. $201 \quad$ p 